\title{
Brain pH Responses to Acetazolamide and Hypercapnia in Cats
}

\author{
Kiyotaka KOHSHI*,**, Yoshimasa KINOSHITA*, and Koichi FUKATA*** \\ Departments of *Neurosurgery and ${ }^{* *}$ Hyperbaric Medicine, School of Medicine, \\ and ${ }^{* * *}$ Division of Clinical Examination, School of Medical Technology, \\ University of Occupational and Environmental Health, Kitakyushu, Fukuoka
}

\begin{abstract}
The involvement of increased brain tissue $\mathrm{CO}_{2}$ tension in acetazolamide-induced brain acidosis was investigated by comparing the brain $\mathrm{pH}$ response to acetazolamide with that to hypercapnia. $\mathrm{CO}_{2}$ and $\mathrm{pH}$ sensors were placed bilaterally into cerebral white matter to $15 \mathrm{~mm}$ depth in cats. Group 1 cats $(\mathrm{n}=9)$ breathed spontaneously, and in situ brain tissue $\mathrm{P}_{\mathrm{CO}_{2}}$ and $\mathbf{p H}\left(\mathrm{Pb}_{\mathrm{CO}_{2}}\right.$ and $\left.\mathrm{pHb}\right)$ were measured after intravenous acetazolamide administration $(20 \mathrm{mg} / \mathrm{kg})$. Group 2 cats $(\mathrm{n}=\mathrm{g})$ were paralyzed and ventilated mechanically, and the changes of $\mathrm{pHb}$ were investigated by adjusting the ventilation to maintain the same $\mathrm{Pb}_{\mathrm{CO}_{2}}$ values as in the acetazolamide-treated group. $\mathrm{Pb}_{\mathrm{CO}_{2}}$ changes were not significantly different between the two groups. However, pHb responses were quite different: the fall in pHb was progressive in Group 1 but transient in Group 2. Brain acidosis after acetazolamide administration is not due to the rise in brain tissue $\mathrm{CO}_{2}$ tension.
\end{abstract}

Key words: carbonic anhydrase, acetazolamide, $\mathrm{pH}$ regulation, cerebrovascular diseases

\section{Introduction}

Measurements of regional cerebral blood flow (CBF) have been used to evaluate the hemodynamic significance of ischemic cerebrovascular disease. Assessment of the capacity to increase CBF in response to vasodilators such as $\mathrm{CO}_{2}$ or acetazolamide is another way of measuring cerebral circulatory reserve.

Acetazolamide, a selective inhibitor of carbonic anhydrase, is more easily administered to patients with cerebrovascular disease than $\mathrm{CO}_{2}$, because it has little influence on the cardiopulmonary system. ${ }^{11,27)}$ Acetazolamide increases the $\mathrm{CBF}$ remarkably and induces an increase in both brain tissue $\mathrm{P}_{\mathrm{CO}_{2}}$ $\left(\mathrm{Pb}_{\mathrm{CO}_{2}}\right)$ and carbonic acidosis, but the mechanisms for these effects have remained obscure. Moreover, there is a dissociation between the changes in $\mathrm{Pb}_{\mathrm{CO}_{2}}$ and brain tissue $\mathrm{pH}(\mathrm{pHb})$; the fall in $\mathrm{pHb}$ is large despite the rise in $\mathrm{Pb}_{\mathrm{CO}_{2}}$ being only slight after acetazolamide administration., ${ }^{48,30]}$ The effects of acetazolamide on the acid-base balance might occur via a direct inhibition of carbonic anhydrase local-

Received April 17, 1996; Accepted November 26, 1996 ized on brain cells. ${ }^{4,30]}$ However, the effects may be due to carbonic anhydrase inhibition in red blood cells (RBCs), ${ }^{21,22,31)}$ because acetazolamide injected intravenously crosses the blood-brain barrier (BBB) slowly, ${ }^{21,23,29)}$ whereas both $\mathrm{Pb}_{\mathrm{CO}_{2}}$ and $\mathrm{pHb}$ change rapidly immediately after intravenous administration of acetazolamide, ${ }^{4,10,21,22.28)}$ If these effects are caused only by disturbance of the $\mathrm{CO}_{2}$-carrying capacity of RBCs, the $\mathrm{pH}$ responses to both acetazolamide and hypercapnia should be similar if the time course of $\mathrm{Pb}_{\mathrm{CO}_{2}}$ is similar.

The recent development of the ion-sensitive fieldeffect transistor (ISFET) allows the measurement of $\mathrm{P}_{\mathrm{CO}_{2}}$ and $\mathrm{pH}$ in situ. ${ }^{7,25)}$ In animal and clinical experiments, catheter-tip $\mathrm{CO}_{2}$ and $\mathrm{pH}$ sensors based on ISFET technology have been successfully used to monitor continuously in situ $\mathrm{P}_{\mathrm{CO}_{2}}$ and $\mathrm{pH}$ in blood and tissues. ${ }^{18,25]}$ The present study investigated whether acetazolamide-induced brain acidosis is due to the concomitant rise in brain tissue $\mathrm{CO}_{2}$ tension.

\section{Materials and Methods}

Twenty-two cats of both sexes (body weight $3.4 \pm$ $0.3 \mathrm{~kg}$, mean $\pm \mathrm{SD}$ ) were sedated with an in- 
traperitoneal injection of $120 \mathrm{mg}$ ketamine. Anesthesia was maintained by continuous infusion of ketamine $(200 \mathrm{mg}$ in $10 \mathrm{ml}$ physiological saline) delivered at $2 \mathrm{ml} / \mathrm{hr}$ via a femoral venous catheter. The animals had miotic eyes and salivation during the measurements. Rectal temperature was monitored and kept at $38^{\circ} \mathrm{C}$ by means of a heating table. Arterial and venous catheters were inserted so that arterial $\mathrm{P}_{\mathrm{CO}_{2}}\left(\mathrm{~Pa}_{\mathrm{CO}_{2}}\right)$ could be monitored continuously and drugs could be infused. The animals were fixed to a stereotactic cradle, and a midline scalp incision was made after local anesthesia with $1 \%$ lidocaine. After the scalp was retracted, two holes of $0.5 \mathrm{~cm}$ diameter were drilled bilaterally through the cranium with a burr drill. Hemostasis was achieved with cauterization and bone wax. The centers of the holes were $1.0 \mathrm{~cm}$ anterior from the ears and $1.0 \mathrm{~cm}$ lateral from the midline. The exposed dura was coagulated and incised.

$\mathrm{CO}_{2}$ and $\mathrm{pH}$ sensors $\left(\mathrm{CO}_{2}\right.$ sensor, $\mathrm{CO}-1035$; $\mathrm{pH}$ sensor, pH-2135; Nihon Kohden, Tokyo) used cathetertip electrodes which contained the pH-ISFET. The $\mathrm{CO}_{2}$ sensor was coated with silicone, and the $\mathrm{pH}$ sensor was encapsulated in the end of a nylon tube. These $\mathrm{CO}_{2}$ and $\mathrm{pH}$ sensors can measure continuously in situ $\mathrm{P}_{\mathrm{CO}_{2}}$ and $\mathrm{pH}$, respectively, in blood and other tissues. ${ }^{18,25)}$ The $\mathrm{pH}$ sensor reveals rapid responses to acidosis and alkalosis, and the response time of the $\mathrm{CO}_{2}$ sensor is 2 minutes for a $90 \%$ change in $\mathrm{CO}_{2}$ tension. ${ }^{25}$ The $\mathrm{pH}$ sensor was calibrated at $37^{\circ} \mathrm{C}$ with a standard phosphate buffer of $\mathrm{pH} 7.27$, and the $\mathrm{CO}_{2}$ sensor was calibrated at $37^{\circ} \mathrm{C}$ with sterile $\mathrm{P}_{\mathrm{CO}_{2}}$ standard solutions of 36 and $86 \mathrm{mmHg}$. The baseline drift of the $\mathrm{CO}_{2}$ sensor was less than 2 mmHg during 5 hours of measurements. ${ }^{181}$ The $\mathrm{CO}_{2}$ and $\mathrm{pH}$ sensors were inserted bilaterally to $15 \mathrm{~mm}$ depth from the cortical surface in the center of the holes. Another $\mathrm{CO}_{2}$ sensor was inserted via a femoral arterial catheter to measure $\mathrm{Pa}_{\mathrm{CO}_{z}}$ continuously. $\mathrm{pH} / \mathrm{P}_{\mathrm{CO}_{2}}$ monitors (KR-5000; Nihon Kohden) were used to record the output of the $\mathrm{CO}_{2}$ and $\mathrm{pH}$ sensors. Respiratory rate was monitored by the impedance method and averaged every 10 seconds, and heart rate was determined from the electrocardiogram.

Two groups of cats were studied. The first (Group 1) was designed to study the effects of acetazolamide and the second (Group 2) to study those of hypercapnia. Group 1 animals $(n=9)$ were allowed to breath spontaneously for at least 30 minutes to let all parameters stabilize. At time 0 (control), after determination of all steady-state values, they received a bolus injection of $20 \mathrm{mg} / \mathrm{kg}$ acetazolamide dissolved in physiological saline (at a concentration of $100 \mathrm{mg}$ / $\mathrm{ml}$ ) via a femoral catheter. During the next 60 minutes, the animals remained in the cradle to monitor the parameters, and in situ $\mathrm{Pb}_{\mathrm{CO}_{2}}$ and $\mathrm{pHb}$ were measured continuously. Group 2 animals $(n=9)$ underwent tracheotomy and muscle paralysis was achieved with intravenous pancuronium $(1.0 \mathrm{mg} / \mathrm{kg} /$ hr). They were mechanically ventilated with air with a Harvard respirator (model 665d; Harvard Apparatus, South Natick, Mass., U.S.A.). $\mathrm{Pb}_{\mathrm{CO}_{2}}$ was controlled by mechanical ventilation to maintain the mean $\mathrm{PaCO}_{2}$ value at that measured during the preacetazolamide period in Group 1 animals. Then, by reducing the rate and depth of respiration, $\mathrm{PaCO}_{2}$ was elevated to the mean $\mathrm{Pb}_{\mathrm{CO}_{2}}$ value measured after acetazolamide injection within 10 minutes to reflect the $\mathrm{Pb}_{\mathrm{CO}_{2}}$ change, because hypoxemia is not induced by hypercapnia ${ }^{20,33)}$ and the $\mathrm{P}_{\mathrm{CO}_{2}}$ gradient between the brain and arterial blood is constant. ${ }^{16)}$ The mechanically induced $\mathrm{Pa}_{\mathrm{CO}_{2}}$ elevation was maintained for more than 60 minutes. All parameters were recorded every 10 seconds by a programmable data logger (7V07; NEC San-Ei, Tokyo).

The obtained data were averaged over 1 minute (6 points) in each animal and analyzed using the Statview statistical package (Abacus Concepts). All values are reported as means $\pm \mathrm{SE}$. Within each group, significant differences between time points were determined by one-way analysis of variance followed by Fisher's least significance test. For intergroup comparison of $\mathrm{Pb}_{\mathrm{CO}_{2}}$ values, two-tailed unpaired $t$ tests were applied. Statistical significance was taken as a $p$ value of $<0.05$.

\section{Results}

Satisfactory recordings of $\mathrm{PaCO}_{2}, \mathrm{~Pb}_{\mathrm{CO}_{2}}$, and $\mathrm{pHb}$ were obtained in 18 of 22 cats. The results in other animals, which developed bleeding at some point in the study, were discarded. The effects of acetazolamide and hypercapnia on $\mathrm{Pa}_{\mathrm{CO}_{2}}, \mathrm{~Pb}_{\mathrm{CO}_{2}}$, and pHb are summarized in Table 1.

The changes in $\mathrm{Pa}_{\mathrm{CO}_{2}}, \mathrm{~Pb}_{\mathrm{CO}_{2}}$, and $\mathrm{pHb}$ are illustrated by the representative electrode tracings from a Group 1 animal (Fig. 1). Acetazolamide administration was always followed by a rapid rise in $\mathrm{Pb}_{\mathrm{CO}_{2}}$, as well as by a concomitant fall in pHb. Such $\mathrm{Pb}_{\mathrm{CO}_{2}}$ changes always reached a steady-state value by 20 minutes after drug administration, and always persisted for at least 40 minutes. The mean $\mathrm{Pb}_{\mathrm{CO}_{2}}$ value increased by $25.3 \pm 5.6 \mathrm{mmHg}$ at 60 minutes after acetazolamide administration. In contrast, the fall in $\mathrm{pHb}$ gradually progressed during the measurements. $\mathrm{pHb}$ decreased by $0.20 \pm 0.04 \mathrm{pH}$ in 60 minutes. $\mathrm{Pa}_{\mathrm{CO}_{2}}$ showed a transient slight rise immediately after acetazolamide administration and then decreased gradually, reaching a steady state at 10 minutes after 
Table 1 Effects of acetazolamide and hypercapnia on $\mathrm{Pb}_{\mathrm{CO}_{2}}$ and $\mathrm{pHb}$

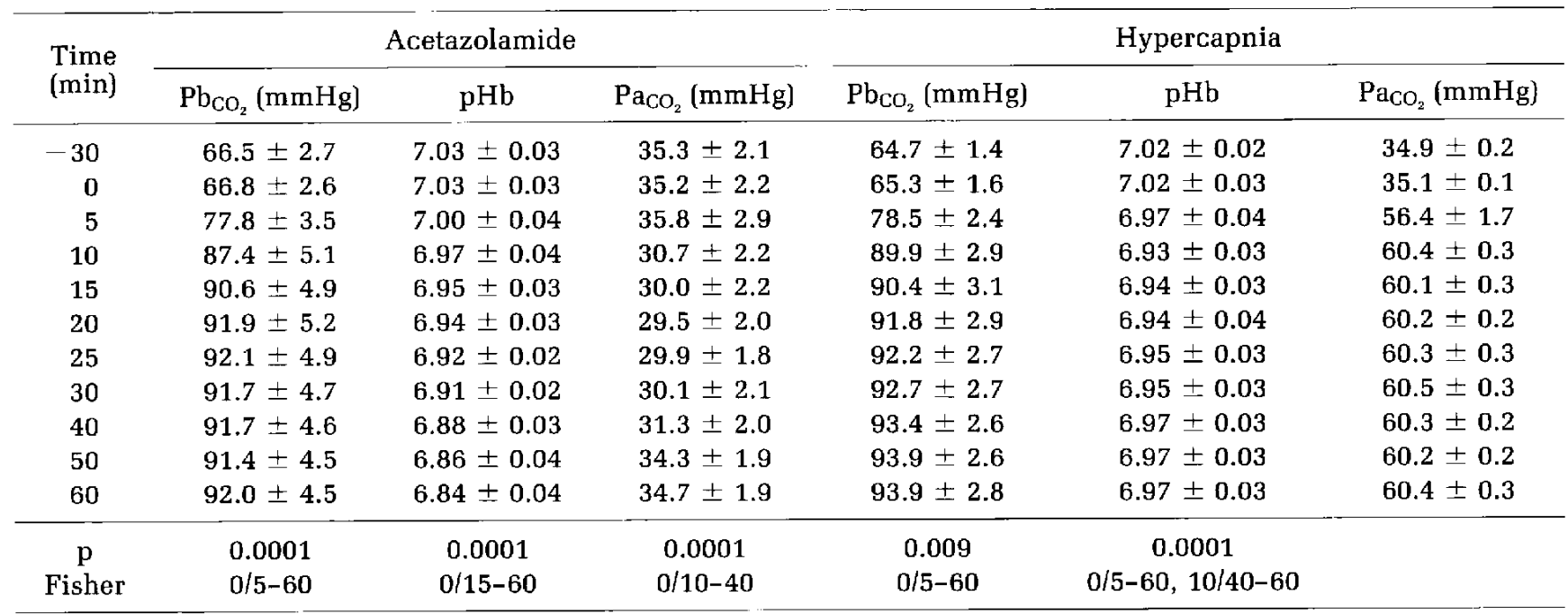

Values are means $\pm \mathrm{SE} . \quad \mathrm{Pa}_{\mathrm{CO}_{2}}$ and $\mathrm{Pb}_{\mathrm{CO}_{2}}$ : arterial and brain tissue $\mathrm{P}_{\mathrm{CO}_{2}}$, $\mathrm{pHb}$ : brain tissue $\mathrm{pH}$. Time 0 min indicates acetazolamide $(20 \mathrm{mg} / \mathrm{kg}$, i.v.) administration and reducing respiration. p and Fisher values were determined by analysis of variance.

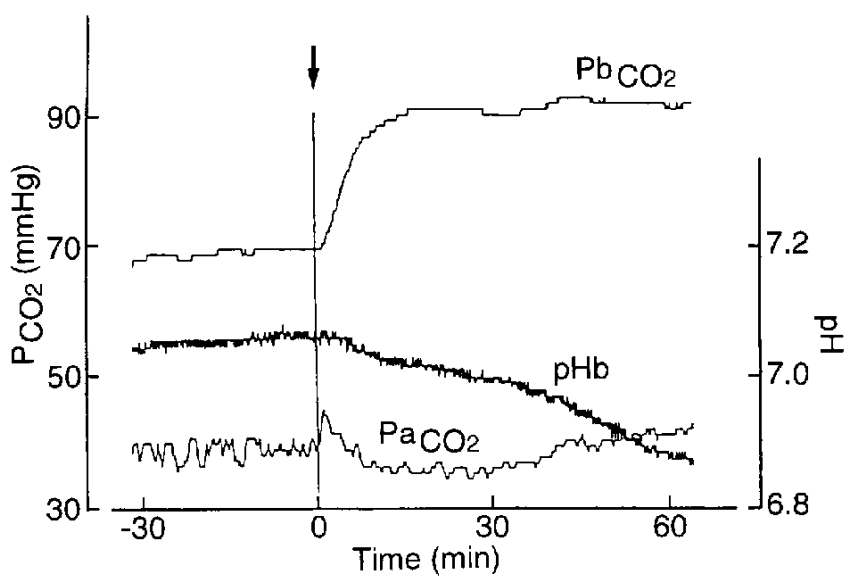

Fig. 1 Representative $\mathbf{P a}_{\mathrm{CO}_{2}}, \quad \mathbf{P b}_{\mathrm{CO}_{2}}$, and $\mathbf{p H b}$ changes in a Group 1 cat. Arrow indicates the time of intravenous administration of $20 \mathrm{mg} / \mathrm{kg}$ of acetazolamide.

drug infusion. The fall in $\mathrm{PaCO}_{2}$ was maintained from 10 to 40 minutes. After this plateau phase, $\mathrm{PaCO}_{2}$ increased gradually and reached a new steady-state value, which was not statistically different from the control value. No significant changes were found in respiratory and heart rates at any point.

Figure 2 shows representative tracings for $\mathrm{PaCO}_{2}$, $\mathrm{Pb}_{\mathrm{CO}_{2}}$, and $\mathrm{pHb}$ in a Group 2 animal. The $\mathrm{Pa}_{\mathrm{CO}_{2}}$ was maintained at $35 \pm 1 \mathrm{mmHg}$ to match the $\mathrm{Pb}_{\mathrm{CO}_{2}}$ to the control $\mathrm{Pb}_{\mathrm{CO}_{2}}$ values in Group 1. $\mathrm{Pa}_{\mathrm{CO}_{2}}$ was increased by hyperventilation sufficient to increase $\mathrm{Pb}_{\mathrm{CO}_{z}}$ by $25 \mathrm{mmHg}$, i.e., the increase caused by

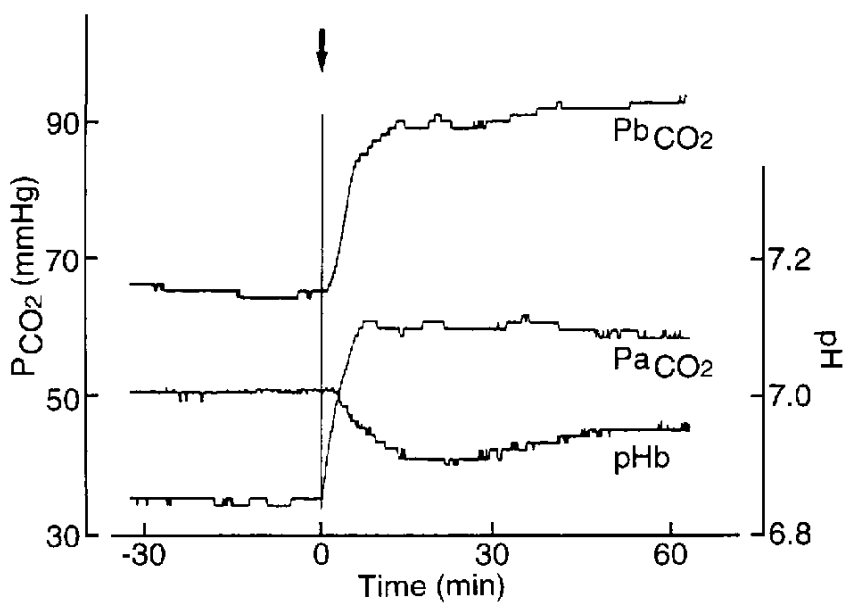

Fig. 2 Representative $\mathrm{Pa}_{\mathrm{Co}_{2}}, \mathrm{~Pb}_{\mathrm{CO}_{2}}$, and $\mathbf{p H b}$ changes in a Group 2 cat. Arrow indicates the time at which hypercapnia was induced.

acetazolamide administration. $\mathrm{pHb}$ decreased from the baseline to the lowest value of $6.93 \mathrm{pH}$ after 10 minute exposure to hypercapnia, and thereafter showed a significant rise from 40 minutes ( $p<0.05$ ). Heart rate decreased transiently after changing the ventilation and soon returned to the baseline.

The baseline values in $\mathrm{Pb}_{\mathrm{CO}_{2}}$ and $\mathrm{pHb}$ in the two groups were not significantly different. Reduction in the rate and depth of respiration changed $\mathrm{Pb}_{\mathrm{CO}_{2}}$ values similarly to those of the acetazolamide-treated animals. However, the time courses of $\mathrm{pHb}$ 


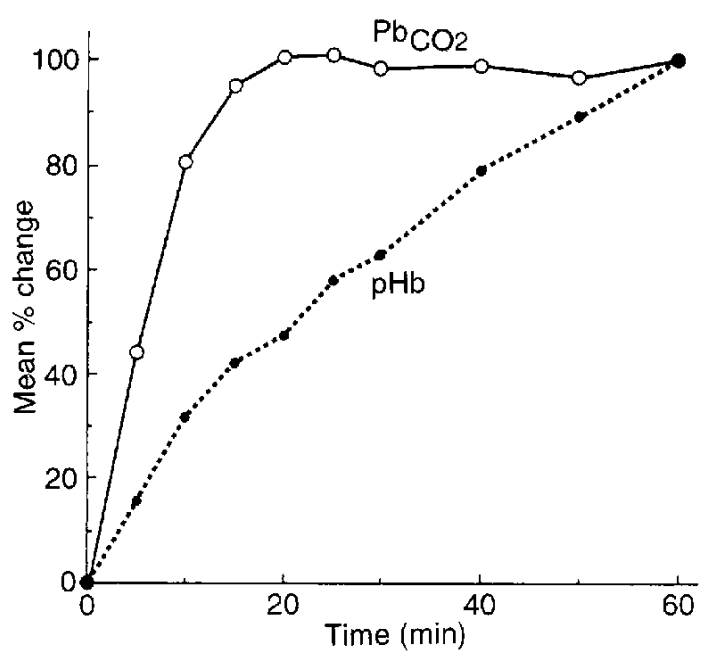

Fig. 3 Mean percentage changes in $\mathrm{Pb}_{\mathrm{co}_{z}}$ and $\mathrm{pHb}$ after intravenous $20 \mathrm{mg} / \mathrm{kg}$ acetazolamide administration.

changes in the two groups were quite different.

\section{Discussion}

This study found differences in both the trend and the magnitude of brain acidosis due to treatment with acetazolamide and hypercapnia despite maintenance of $\mathrm{Pb}_{\mathrm{CO}_{2}}$ at similar levels.

The time course of the mean percentage changes in $\mathrm{Pb}_{\mathrm{CO}_{2}}$ and $\mathrm{pHb}$ were quite different in animals treated with acetazolamide (Fig. 3), although the response time of the $\mathrm{CO}_{2}$ sensor is slower than that of the $\mathrm{pH}$ sensor. This finding is in contrast to previous observations of the same mean percentage changes in $\mathrm{P}_{\mathrm{CO}_{2}}$ and $\mathrm{pH}$ at the medullary surface. ${ }^{28)}$ However, measurement of $\mathrm{P}_{\mathrm{CO}_{2}}$ and $\mathrm{pH}$ at the brain surface found a fall in $\mathrm{pH}$ persisted whereas $\mathrm{P}_{\mathrm{CO}_{2}}$ was reduced to the control values before treatment through changes in ventilation. ${ }^{4)}$ The reaction $\left(\mathrm{CO}_{2}\right.$ $+\mathrm{H}_{2} \mathrm{O}=\mathrm{H}_{2} \mathrm{CO}_{3}=\mathrm{H}^{+}+\mathrm{HCO}_{3}{ }^{-}$) requires 20 seconds to reach $90 \%$ change of the total change in plasma. ${ }^{a]}$ The same time is estimated to be required to reach equilibrium in brain extracellular fluid because carbonic anhydrase is not present there. If both $\mathrm{P}_{\mathrm{CO}_{2}}$ and $\mathrm{pH}$ are regulated together by this equilibrium reaction in brain extracellular fluid, then such a large difference in the mean percentage change would not occur even if the hydration reaction of $\mathrm{CO}_{2}$ is uncatalyzed. Therefore, the previous and our present findings indicate that both brain $\mathrm{H}^{+}$ and $\mathrm{CO}_{2}$ can increase independently in response to acetazolamide.

The exact mechanisms by which acetazolamide induces a rise in $\mathrm{Pb}_{\mathrm{CO}_{2}}$ and brain acidification have not been clarified. The importance of carbonic anhydrase in brain tissue has been emphasized in the rise in $\mathrm{Pb}_{\mathrm{CO}_{2}},{ }^{43}$ but carbonic anhydrase inhibition in RBCs causes both decreased $\mathrm{CO}_{2}$-carrying capacity of blood and greater $\mathrm{P}_{\mathrm{CO}_{2}}$ gradient between tissue and blood, ${ }^{5,21,22,31]}$ because acetazolamide injected intravenously penetrates the BBB slowly and may take several hours before the physiological effect is maximum. ${ }^{21,23.29)}$ The overall pattern of carbonic anhydrase inhibition by acetazolamide injected intravenously is simply due to the greatly increased gradient of $\mathrm{P}_{\mathrm{CO}_{2}}$ from tissue to alveolus. ${ }^{21]} \mathrm{Mem}$ brane-associated carbonic anhydrase is widely present on the luminal surface of endothelial cells of brain capillaries. ${ }^{9)}$ This type of carbonic anhydrase is present in the lungs ${ }^{32]}$ and is involved in $\mathrm{CO}_{2}$ exclusion from the lungs. ${ }^{6)}$ The carbonic anhydrase in brain capillaries is probably important for $\mathrm{CO}_{2}$ transport from the brain to blood and inhibition may cause $\mathrm{CO}_{2}$ retention in the brain. ${ }^{9,19)}$ Therefore, there are at least two sources for the rise in $\mathrm{Pb}_{\mathrm{CO}_{2}}$ after acetazolamide administration: inhibition of carbonic anhydrase located either in RBCs or in brain capillary endothelium.

Brain carbonic acidosis might occur via direct inhibition of carbonic anhydrase located in brain tissue, but the slow movement of acetazolamide across the $\mathrm{BBB}$ suggests that the rapid pHb change after drug administration is not caused by this mechanism. The excess rise in $\mathrm{Pb}_{\mathrm{CO}_{2}}$ after acetazolamide administration may cause the formation of carbonic acid in brain tissue. ${ }^{22,281}$ According to this hypothesis, $\mathrm{pHb}$ responses to both acetazolamide and hypercapnia should be similar if the time course of $\mathrm{Pb}_{\mathrm{CO}_{2}}$ is the same. However, our study found the fall in $\mathrm{pHb}$ was progressive after acetazolamide administration, but transient in hypercapnia.

The $\mathrm{pHb}$ response to hypercapnia shows the phenomenon of $\mathrm{pH}$ buffering in brain extracellular fluid due to carbonic anhydrase in RBCs and brain tissue. Such brain pH buffering capacity is well known to be activated under hypercapnia and hypocapnia. ${ }^{1,2)}$ Our result that the pHb buffering is inhibited by acetazolamide administration suggests that one of the $\mathrm{pHb}$ regulating mechanisms is carbonic anhydrase-dependent. Brain $\mathrm{pH}$ is regulated mainly by transmembrane ion transport in both the brain capillary wall and the brain cell membrane. ${ }^{14,24)}$ Especially, $\mathrm{Na}^{+} / \mathrm{H}^{+}$and $\mathrm{Cl}^{-} / \mathrm{HCO}_{3}{ }^{-}$exchanges are important in brain $\mathrm{pH}$ regulation. ${ }^{3,12,14)}$ In the cerebrospinal fluid, $\mathrm{Na}^{+} / \mathrm{H}^{+}$and $\mathrm{Cl}^{-} / \mathrm{HCO}_{3}{ }^{-}$ exchanges may be dependent on carbonic anhydrase located in the cells of the choroid plexus and glia. ${ }^{15,26)}$ Our result that acetazolamide inhibited $\mathrm{pHb}$ regulation is similar to the observation that in- 
traperitoneal acetazolamide interfered with carbonic anhydrase-dependent ion transport in the brain cell membrane. ${ }^{17]}$ However, we believe that this phenomenon cannot be explained by this site of inhibition because of the slowness of acetazolamide penetration across the BBB. Intra- and extracellular $\mathrm{pH}$ changes are interdependent in brain tissue. ${ }^{13)}$ Thus, the inhibition of intracellular $\mathrm{pH}$ regulation might be greatly affected by the extracellular $\mathrm{pH}$ change. Although our data support the hypothesis that brain capillary endothelial carbonic anhydrase interferes with $\mathrm{pH}$ regulation in brain tissue, how intravenously injected acetazolamide affects the $\mathrm{pH}$ regulatory mechanism is not shown.

The $\mathrm{pHb}$ responses to acetazolamide and hypercapnia are quite different from each other when the values of $\mathrm{Pb}_{\mathrm{CO}_{2}}$ are not significantly different at any point during the measurement. Acetazolamide-induced brain carbonic acidosis is not due to the concomitant rise in brain tissue $\mathrm{CO}_{2}$ tension.

\section{References}

1) Adler $S$, Simplaceanu V, Ho C: Determination of rat brain buffering in vivo by ${ }^{31}$ P-NMR. J Appl Physiol 64: 1829-1836, 1988

2) Arieff AI, Kerian A, Massry SG, DeLima J: Intracellular $\mathrm{pH}$ of brain: Alterations in acute respiratory acidosis and alkalosis. Am J Physiol 230: 804-812, 1976

3) Bets AL: Sodium transport in capillaries isolated from rat brain. J Neurochem 41: 1150-1157, 1983

4) Bickler PE, Litt L, Banville DL, Severinghaus JW: Effects of acetazolamide on cerebral acid-base balance. J Appl Physiol 65: 422-427, 1988

5] Brzezinski J, Kjällquist $\AA$, Siesjö BK: Mean carbon dioxide tension in the brain after carbonic anhydrase inhibition. J Physiol (Lond) 188: 13-23, 1967

6) Effros RM, Chang RSY, Silverman P: Acceleration of plasma bicarbonate conversion to carbon dioxide by pulmonary carbonic anhydrase. Science 199: 427429, 1978

7) Esashi M, Matsuo T: Integrated micro multi ion sensor using field effect of semiconductor. IEEE Trans Biomed Eng 25: 184-192, 1978

8) Forster RE, Crandall ED: Time course of exchanges between red cells and extracellular fluid during $\mathrm{CO}_{2}$ uptake. J Appl Physiol 38: 710-718, 1975

9) Ghandour MS, Langley OK, Zhu XL, Waheed A, Sly WS: Carbonic anhydrase IV on brain capillary endothelial cells: A marker associated with the bloodbrain barrier. Proc Natl Acad Sci U S A 89: 68236827, 1992

10 Heuser D, Astrup J, Lassen NA, Betz E: Brain carbonic acid acidosis after acetazolamide. Acta Physiol Scand 93: 385-390, 1975

11) Højer-Pedersen E: Effect of acetazolamide on cerebral blood flow in subacute and chronic cerebrovascular disease. Stroke 18: 887-891, 1987
12) Javaheri S, De Hemptinne A, Vanheel B, Leusen I: Changes in brain ECF pH during metabolic acidosis and alkalosis: A microelectrode study. J Appl Physiol 55: 1849-1853, 1983

13) Jean $T$, Frelin C, Vigne $P$, Lazdunski $M$ : The $\mathrm{Na}^{+} / \mathrm{H}^{+}$ exchange system in glial cell lines: Properties and activation by an hyperosmotic shock. Eur J Biochem 160: 211-219, 1986

14) Katsura K, Kristián T, Nair R, Siesjö BK: Regulation of intra- and extracellular $\mathrm{pH}$ in the rat brain in acute hypercapnia: A re-appraisal. Brain Res 651: 47-56, 1994

15) Kazemi $\mathrm{H}$, Choma $\mathrm{L}: \mathrm{H}^{+}$transport from CNS in hypercapnia and regulation of $\mathrm{CSF}\left[\mathrm{HCO}_{3}^{-}\right]$. J Appl Physiol 42: 667-672, 1977

16) Kennealy JA, McLennan JE, Loudon RG, McLaurin RL: Hyperventilation-induced cerebral hypoxia. Am Rev Respir Dis 122: 407-412, 1980

17) Kjällquist $\AA$, Messeter $\mathrm{K}$, Siesjö BK: The in vivo $\mathrm{CO}_{2}$ buffer capacity of rat brain tissue under carbonic anhydrase inhibition. Acta Physiol Scand 78: 94-102, 1970

18) Kohama A, Nakamura $Y$, Nakamura M, Yano $M$, Shibatani K: Continuous monitoring of arterial and tissue $\mathrm{P}_{\mathrm{CO}_{2}}$. Crit Care Med 12: 940-942, 1984

19) Kohshi K, Konda N, Kinoshita Y, Tsuru E, Yokota A: In situ arterial and brain tissue $\mathrm{P}_{\mathrm{CO}_{2}}$ responses to acetazolamide in cats. J Appl Physiol 76: 2199-2203, 1994

20) Kohshi K, Yokota A, Konda N, Kinoshita Y, Kajiwara $H$ : Intracranial pressure responses during hyperbaric oxygen therapy. Neurol Med Chir (Tokyo) 31: 575581, 1991

21) Maren TH: Carbonic anhydrase: Chemistry, physiology, and inhibition. Physiol Rev 47: 595-781, 1967

22) Meyer JS, Gotoh F: Interaction of cerebral hemodynamics and metabolism. Neurology 11: 4665, 1961

23) Roth LJ, Schoolar JC, Barlow CF: Sulfur- ${ }^{35}$ labeled acetazolamide in cat brain. J Pharmacol Exp Ther 125: 128-136, 1959

24) Seifter JL, Aronson PS: Properties and physiologic roles of the plasma membrane sodium-hydrogen exchanger. J Clin Invest 78: 859-864, 1986

25) Shimada K, Yano M, Shibatani K, Komoto Y, Esashi M, Matsuo T: Application of catheter-tip i.s.f.e.t. for continuous in vivo measurement. Med Biol Eng Comput 18: 741-745, 1980

26) Siesjö BK, Kjällquist $\AA$ : A new theory for the regulation of the extracellular $\mathrm{pH}$ in the brain. Scand J Clin Lab Invest 24: 1-9, 1969

27) Sullivan HG, Kingsbury TB IV, Morgan ME, Jeffcoat RD, Allison JD, Goode JJ, McDonnell DE: The rCBF response to Diamox in normal subjects and cerebrovascular disease patients. I Neurosurg 67: 525-534, 1987

28) Teppema LJ, Rochette F, Demedts M: Effects of acetazolamide on medullary extracellular $\mathrm{pH}$ and $\mathrm{P}_{\mathrm{CO}_{2}}$ and on ventilation in peripherally chemodenervated cats. Pflugers Arch 415: 519-525, 1990 
29) Travis DM, Wiley C, Maren TH: Respiration during chronic inhibition of renal carbonic anhydrase: Further observations on pharmacology of 2-benzene-sulfonamido-1,3,4-thiadiazole-5-sulfonamide [CL 11366], acetazolamide and methazolamide. J Pharmacol Exp Ther 151: 464-481, 1966

30) Vorstrup S, Brun B, Lassen NA: Evaluation of the cerebral vasodilatory capacity by the acetazolamide test before EC-IC bypass surgery in patients with occlusion of the internal carotid artery. Stroke 17: 1291-1298, 1986

31) Vorstrup S, Henriksen L, Paulson OB: Effect of acetazolamide on cerebral blood flow and cerebral metabolic rate for oxygen. J Clin Invest 74: 16341639, 1984

32) Waheed A, Zhu XL, Sly WS: Membrane-associated carbonic anhydrase from rat lung. J Biol Chem 267: 3308-3311, 1992

33) Zauner A, Bullock R, Di X, Young HF: Brain oxygen, $\mathrm{CO}_{2}, \mathrm{pH}$, and temperature monitoring: Evaluation in the feline brain. Neurosurgery 37: 1168-1177, 1995

Address reprint requests to: K. Kohshi, M.D., Departments of Neurosurgery and Hyperbaric Medicine, School of Medicine, University of Occupational and Environmental Health, 1-1 Iseigaoka, Yahatanishi-ku, Kitakyushu, Fukuoka 807, Japan.

\section{Commentary}

Kohshi et al. have provided important insight into the mechanism of induction of brain acidosis by acetazolamide. In their well designed and creative set of experiments, these investigators have shown clear differences in the temporal profile and magnitude of brain acidosis due to acetazolamide and hypercapnia. By adjusting for $\mathrm{Pb}_{\mathrm{CO}}$ in the two experimental groups, they have shown that the mechanism for acetazolamide-induced brain acidosis is not simply the result of a rise in brain $\mathrm{CO}_{2}$ tension induced by the pharmacologic agent.

As with most good experiments, this study answers an important question and also raises some new unanswered questions that require further investigation. The authors' scholarly discussion applies their novel finding to existing hypotheses on mechanisms by which acetazolamide induces $a$ rise in $\mathrm{Pb}_{\mathrm{CO}_{2}}$ and brain acidification. The results strongly suggest that bгain capillary endothelial carbonic anhydrase interferes with $\mathrm{pH}$ regulation in brain tissue. Further work is indicated to determine the precise mechanism by which acetazolamide affects the $\mathrm{pH}$ regulatory mechanism.

Daniel L. Barrow, M.D. Department of Neurosurgery The Emory Clinic
Georgia, U.S.A.

Dr. Kohshi and his colleagues report interesting data which disclose striking differences in brain tissue $\mathrm{pH}$ responses between acetazolamide administration and hypercapnia. They demonstrate that, when acetazolamide is administered intravenously, the brain tissue $\mathrm{pH}$ decreases slowly, whereas the increase in $\mathrm{CO}_{2}$ tension of the brain tissue reaches its maximum level far more rapidly. In contrast, hypercapnia causes a decrease in $\mathrm{pH}$ in parallel with an increase in $\mathrm{CO}_{2}$ tension within the brain tissue. This difference in immediate responses of the brain tissue pH should be taken into account when cerebrovascular responses are analyzed by these procedures. They also demonstrate that, while the decrease in brain tissue $\mathrm{pH}$ during hypercapnia is transient, acetazolamide causes the brain tissue $\mathrm{pH}$ to decrease progressively. As mentioned by the authors, the slowly progressive decrease in brain tissue $\mathrm{pH}$ caused by acetazolamide may reflect disturbances in the mechanisms of $\mathrm{pH}$ regulation. The authors suggest that inhibition of carbonic anhydrase located on the capillary endothelial cells of the brain could play a major role in producing such disturbances of $\mathrm{pH}$ regulation within the brain tissue. This is another important factor which should be borne in mind when acetazolamide is used clinically.

Yoichi Katayama, M.D. Department of Neurological Surgery Nihon University School of Medicine Tokyo, Japan

Kohshi et al. have used $\mathrm{CO}_{2}$ and $\mathrm{pH}$ sensors, which facilitate continuous monitoring of brain tissue $\mathrm{CO}_{2}$ tension $\left(\mathrm{Pb}_{\mathrm{CO}_{2}}\right)$ and $\mathrm{pH}(\mathrm{pHb})$, and studied the effects of acetazolamide and hypercapnia on $\mathrm{Pb}_{\mathrm{CO}_{2}}$ and $\mathrm{pHb}$. It is well-known that acetazolamide is a potent cerebrovascular dilatator and it is used to examine cerebrovascular reserve capacity in stroke patients. However, the mechanism by which acetazolamide causes tissue acidosis is not completely understood. The authors demonstrated clear $\mathrm{Pa}_{\mathrm{CO}_{2}}, \mathrm{~Pb}_{\mathrm{CO}_{2}}$, and $\mathrm{pHb}$ changes in acetozolamide and hypercapnia groups. Acetazolamide-treated animals showed progressive and persistent falls in $\mathrm{pHb}$ associated with $\mathrm{Pb}_{\mathrm{CO}_{2}}$ rise. Hypercapnia animals showed the same $\mathrm{Pb}_{\mathrm{CO}_{2}}$ rise as seen in acetazolamide-treated animals, but the fall in $\mathrm{pHb}$ was transient. Thus, the $\mathrm{pHb}$ responses to acetazolamide and hypercapnia are quite different when the values of $\mathrm{Pb}_{\mathrm{CO}_{2}}$ are not significantly different at any point during the measurement. They concluded that acetazolamide-induced brain carbonic acidosis was not due to the concomitant rise in brain tissue $\mathrm{CO}_{2}$ tension. This conclu- 
sion rises another question about the discrepancy between the rapidity of the brain acidosis after acetazolamide administration and the slowness of acetazolamide penetration across the BBB. Further new information about the biochemical effects of acetazolamide on cerebral $\mathrm{pH}$ regulation are necessa- ry to answer these complex problems.

Minoru MAEDA, M.D. Department of Neurosurgery Juntendo University Izunagaoka Hospital Shizuoka, Japan 